ARCH. INT. MED.

\title{
II. THE INFLUENCE OF THYROIDECTOMY AND THYROID DISEASES ON PROTEIN METABOLITES *
}

N. W. JANNEY, M.D., AND V. I. ISAACSON, B.S.

I. INTRODUCTION

The endocrine glands undoubtedly play an important rôle in controlling metabolic processes. This field fascinatingly invites research study, both on account of its high scientific interest and its clinical importance. For some time past we have been investigating the influence of the thyroid gland on metabolism. The problems investigated have comprehended the relation of the thyroid to (1) carbohydrate metabolism, (2) protein metabolism and (3) thyroid therapy.

In the present article the influence of the thyroid on certain aspects of protein metabolism are considered. Although it has been known for a long time that the administration of thyroid preparations stimulates protein catabolism, and conversely that the abolition of thyroid function diminishes tissue breakdown, still our knowledge of the influence of the thyroid on specific nitrogen metabolites such as ammonia, creatinin and the purins has remained rudimentary. Better information is here very desirable, since if one could, for example, trace the control of creatinin and purin metabolism to the thyroid or other ductless glands, the curtain obscuring an understanding of the causes of various myopathies and even the gouty diathesis might be raised.

A study of the influence of the thyroid, taken as a type of the endocrine organs, on the nitrogen metabolism is therefore of considerable importance. This problem has been attacked by us from two chief directions. First, we endeavored to learn more about thyroid function by estimating the nitrogenous constituents in the urine of animals before thyroidectomy, and then observing the changes occurring after the operation; that is, the metabolism of experimental athyroidism. Second, the metabolism of experimental hyperthyroidism was studied by following the chemical urinary changes after injecting an overdose of the isolated thyroid hormone. Third, supplemental studies were made in cretinism and exophthalmic goiter, as types of hypothyroidism and hyperthyroidism.

\section{METABOLISM IN EXPERIMENTAL ATHYROIDISM}

1. The Experimental Plan.-This consisted in making a complete quantitative study, that is, partition, of the nitrogenous substances of

* Submitted for publication April 22, 1918.

* From the Montefiore Home and Hospital. 
the urine of fasting dogs and repeating this examination after removal of the thyroid glands. Before and after the operation, the sparing action of glucose on protein metabolism was simultaneously followed for purposes to be mentioned later. The same precautions to insure accuracy in these metabolic experiments were taken as have been described in preceding researches by one of us and his co-workers. ${ }^{1}$

In view of the fact that the same experimental subjects have been used in a recent investigation ${ }^{2}$ on the effect of thyroidectomy on the blood sugar, it seems unnecessary to repeat the details here. It may, however, be stated that considerable care was exercised throughout in removing the thyroids and that no parathyroid tetany or other disturbing factors developed. The animals before and after the operation remained in excellent general condition, which fact gives added reliability to the results.

During the experimental periods, both before and after the operation, the dogs received as diet nothing but 40 c.c. water per kilogram of body weight, except on the sugar days, when $6.5 \mathrm{gm}$. glucose for every kilogram of the animal's weight were dissolved in this amount of water and administered by mouth. By this means the results of the metabolic study before and after thyroidectomy are to be regarded as mutually comparable.

In making the nitrogen partitions the following substances were determined with methods as indicated: total nitrogen, Kjeldahl; urea nitrogen, Van Slyke and Cullen ; ammonia nitrogen, Van Slyke and Cullen $;^{3}$ creatinin, Folin and Morris $;^{4}$ creatin, Benedict $;^{5}$ purin nitrogen, Camerer-Arnstein. ${ }^{6}$ In order to make the analytical data clearer, they are expressed in terms of the nitrogen content of the substances determined and in terms of the percentile amounts they represent of the total nitrogen excreted each day.

2. Results.-Adult dogs bear the effects of thyroidectomy remarkably well. Some of our animals lived comfortably for many months after the operation and without any obvious symptoms. This is to be explained by the fact that endocrine activity is probably lessened in the adult. Dr. F. M. Allen informs us that he has had similiar experience with thyroidectomized dogs at the Rockefeller Institute. Had it been practical to use young puppies for such difficult experiments, it is possible that the metabolic changes would have been more marked

1. Janney, N. W.: Jour. Biol. Chem., 1915, 20, 321.

2. Janney, N. W., and Isaacson, V. I.: The Blood Sugar in Thyroid and Other Endocrine Diseases, The Archives Int. Med., this issue.

3. Van Slyke, D. D., and Cullen, G. E.: Jour. Biol. Chem., 1914, 19, 211.

4. Folin, O., and Morris, J. L.: Jour. Biol. Chem., 1914, 17, 469.

5. Benedict, S. R.: Jour. Biol. Chem., 1914, 18, 191.

6. Method of Camerer-Arnstein, "Analyse des Harns," Neubauer-Huppert, $1913,2,941$. 
TABLE 1.-Dog 1. Nitrogen Partition BEFORE THYROIDECTOMY

\begin{tabular}{|c|c|c|c|c|c|c|c|c|c|c|c|c|c|c|c|c|c|}
\hline \multirow{2}{*}{ Day } & \multirow{2}{*}{$\begin{array}{l}\text { Wt., } \\
\text { Kg. }\end{array}$} & \multirow{2}{*}{$\begin{array}{l}\text { Glu. } \\
\text { cose, } \\
\text { Fed, } \\
\text { Gm. }\end{array}$} & \multirow{2}{*}{$\begin{array}{l}\text { Vol. } \\
\text { Urine, } \\
\text { C.c. }\end{array}$} & \multirow{2}{*}{$\begin{array}{c}\text { Total } \\
\text { N, } \\
\text { Gm. }\end{array}$} & \multirow{2}{*}{$\begin{array}{c}\mathrm{N} \\
\text { per } \\
\text { Kg. }\end{array}$} & \multicolumn{2}{|c|}{ Urea $\mathbf{N}$} & \multicolumn{2}{|c|}{$\underset{\mathrm{N}}{\mathrm{NH}_{3}}$} & \multicolumn{2}{|c|}{ Purin } & \multicolumn{2}{|c|}{ Creatin } & \multicolumn{2}{|c|}{$\underset{\mathbf{N}}{\text { Creatinin }}$} & \multicolumn{2}{|c|}{$\underset{\mathbf{N}}{\text { Rest }}$} \\
\hline & & & & & & Gm. & $\%$ & Gmo. & $\%$ & Gm. & $\%$ & $\mathrm{Gm}$. & $\%$ & Gm. & $\%$ & Gm. & $\%$ \\
\hline 1 & 10.8 & $\cdots$ & 360 & 3.00 & 0.278 & & $\cdots$ & & & & & & & & & & \\
\hline 2 & 10.6 & ... & 370 & 2.58 & 0.243 & $\ldots$ & .... & $\cdots$ & .. & 0.013 & 0.50 & & & & & & \\
\hline 3 & 10.5 & $\ldots$ & 380 & 2.37 & 0.228 & $\ldots$ & $\ldots$ & $\ldots$. & .. & 0.012 & 0.50 & & & & & & \\
\hline 4 & 10.4 & & 400 & 2.33 & 0.226 & & .... & 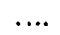 & .. & 0.011 & 0.48 & & & & & & \\
\hline 5 & 10.3 & 154.5 & 440 & 2.03 & 0.197 & 1.33 & 65 & 0.17 & 8 & 0.011 & 0.54 & 0.081 & 3.9 & 0.038 & 1.8 & 0.40 & 19 \\
\hline 6 & 10.3 & 154.5 & 330 & 1.60 & 0.155 & 1.01 & 63 & 0.20 & 12 & 0.010 & 0.55 & 0.085 & 5.3 & 0.048 & 3.0 & 0.25 & 15 \\
\hline 7 & 10.3 & 154.5 & 340 & 1.67 & 0.162 & 1.12 & 67 & 0.21 & 12 & 0.009 & 0.54 & 0.085 & 5.0 & 0.035 & 2.0 & 0.21 & 12 \\
\hline 8 & 10.1 & $\ldots$ & 380 & 2.10 & 0.208 & 1.54 & 73 & 0.17 & 8 & 0.010 & 0.48 & 0.081 & 3.8 & 0.038 & 1.8 & 0.26 & 12 \\
\hline 9 & 9.9 & .. & 415 & 2.10 & 0.212 & 1.52 & 72 & 0.16 & 8 & 0.010 & 0.48 & 0.081 & 3.8 & 0.038 & 1.8 & 0.29 & $1 \%$ \\
\hline
\end{tabular}

AFTER THYROIDECTOMY

\begin{tabular}{l|r|r|r|r|r|r|r|r|r|r|r|r|r|r|r|r|r|r}
\hline 1 & 12.2 & $\ldots$ & 600 & 1.65 & 0.136 & 1.16 & 70 & 0.16 & 9 & 0.006 & 0.36 & 0.101 & 6.1 & 0.015 & 0.9 & 0.21 & 13 \\
2 & 11.8 & $\ldots$ & 540 & 1.96 & 0.166 & 1.39 & 73 & 0.17 & 8 & 0.003 & 0.15 & 0.106 & 5.4 & 0.014 & 0.7 & 0.30 & 12 \\
3 & 11.7 & 175.5 & 210 & 1.91 & 0.163 & 1.23 & 64 & 0.18 & 9 & 0.004 & 0.22 & 0.110 & 5.7 & 0.021 & 1.1 & 0.36 & 20 \\
4 & 11.7 & 175.5 & 200 & 1.65 & 0.141 & 1.07 & 65 & 0.21 & 12 & 0.006 & 0.36 & 0.119 & 7.2 & 0.020 & 1.2 & 0.23 & 14 \\
5 & 11.7 & 175.5 & 260 & 1.69 & 0.145 & 0.99 & 60 & 0.22 & 13 & 0.008 & 0.48 & 0.126 & 7.4 & 0.014 & 0.8 & 0.37 & 18 \\
6 & 11.7 & $\ldots$ & 430 & 2.07 & 0.177 & 1.58 & 76 & 0.14 & 7 & 0.006 & 0.29 & 0.106 & 5.1 & 0.035 & 1.7 & 0.20 & 10 \\
7 & 11.5 & $\ldots$ & 440 & 2.07 & 0.180 & 1.61 & 77 & 0.13 & 6 & 0.004 & 0.19 & 0.106 & 5.1 & 0.035 & 1.7 & 0.21 & 10 \\
\hline
\end{tabular}

TABLE 2.-Dog 2. Nitrogen Partition BEFORE THYROIDECTOMY

\begin{tabular}{|c|c|c|c|c|c|c|c|c|c|c|c|c|c|c|c|c|c|}
\hline \multirow{2}{*}{ Day } & \multirow{2}{*}{$\begin{array}{l}\text { Wt., } \\
\text { Kg. }\end{array}$} & \multirow{2}{*}{$\begin{array}{l}\text { Glu- } \\
\text { cose, } \\
\text { Fed, } \\
\text { Gm. }\end{array}$} & \multirow{2}{*}{$\begin{array}{l}\text { Vol. } \\
\text { Urine } \\
\text { C.e. }\end{array}$} & \multirow{2}{*}{$\begin{array}{c}\text { Total } \\
\text { N, } \\
\text { Gm. }\end{array}$} & \multirow{2}{*}{$\begin{array}{l}\mathbf{N} \\
\text { per } \\
\text { Kg. }\end{array}$} & \multicolumn{2}{|c|}{ Urea $N$} & \multicolumn{2}{|c|}{$\underset{\mathrm{N}}{\mathrm{NH}_{3}}$} & \multicolumn{2}{|c|}{ Purin } & \multicolumn{2}{|c|}{$\begin{array}{l}\text { Creatin } \\
\text { N }\end{array}$} & \multicolumn{2}{|c|}{$\underset{\mathbf{N}}{\text { Creatinin }}$} & \multicolumn{2}{|c|}{$\underset{N}{\text { Rest }}$} \\
\hline & & & & & & Gm. & $\%$ & $\mathrm{Gm}$. & $\%$ & Gm. & $\%$ & Gm. & $\%$ & $\mathrm{Gm}$. & $\%$ & Gm. & $\%$ \\
\hline 1 & 17.6 & $\ldots$ & 535 & 3.03 & 0.172 & 2.27 & 74 & 0.21 & 7 & 0.021 & 0.69 & 0.21 & 6.9 & 0.026 & 0.85 & 0.29 & $9 . \overline{5}$ \\
\hline 2 & 17.3 & ... & 575 & 3.11 & 0.180 & 2.44 & 78 & 0.23 & 7 & 0.012 & 0.38 & 0.22 & 7.0 & 0.038 & 1.22 & 0.17 & 5.4 \\
\hline 3 & 16.6 & 249 & 450 & 3.12 & 0.188 & 1.83 & 58 & 0.30 & 9 & 0.030 & 0.96 & 0.23 & 7.3 & 0.016 & 0.51 & 0.71 & 22.7 \\
\hline 4 & 16.6 & 249 & 345 & 2.47 & 0.148 & 1.71 & 69 & 0.24 & 9 & 0.026 & 0.75 & 0.18 & 7.2 & 0.038 & 1.13 & 0.28 & 11.3 \\
\hline 5 & 16.6 & 249 & 510 & 2.55 & 0.154 & 1.79 & 70 & 0.24 & 9 & 0.020 & 0.79 & 0.18 & 7.0 & 0.038 & 1.46 & 0.28 & 10.9 \\
\hline 6 & 16.5 & $\ldots$ & 770 & 3.14 & 0.190 & 2.54 & 80 & 0.21 & 8 & 0.020 & 0.65 & 0.20 & 6.3 & 0.022 & 0.70 & 0.30 & 4.7 \\
\hline
\end{tabular}

AFTER THYROIDECTOMY

\begin{tabular}{r|r|r|r|r|r|r|r|r|r|r|r|r|r|r|r|r|r|r|r}
\hline 1 & 14.9 & $\ldots$ & 610 & 2.22 & 0.149 & $*$ & $\ldots$ & $\ldots$. & $\ldots$ & 0.015 & 0.69 & 0.18 & 8 & $\ldots$. & $\ldots$ & $\ldots$ & $\ldots$ \\
2 & 14.7 & $\ldots$ & 610 & 2.27 & 0.154 & 1.63 & 72 & 0.317 & 14 & 0.006 & 0.26 & 0.18 & 8 & $\ldots$. & $\ldots$. & $\ldots$ & $\ldots$ \\
3 & 14.5 & 217.5 & 610 & 2.58 & 0.177 & 1.96 & 76 & 0.188 & 7 & 0.022 & 0.84 & 0.18 & 7 & 0.022 & 0.86 & 0.21 & 9 \\
4 & 14.5 & 217.5 & 505 & 1.78 & 0.122 & 1.06 & 60 & 0.366 & 20 & 0.020 & 1.10 & 0.17 & 9 & 0.004 & 0.25 & 0.16 & 8 \\
5 & 14.5 & 217.5 & 570 & 1.65 & 0.113 & 1.08 & 66 & 0.206 & 12 & 0.015 & 0.89 & 0.17 & 10 & 0.023 & 1.39 & 0.16 & 9 \\
6 & 14.5 & $\ldots$. & 430 & 2.19 & 0.151 & 1.72 & 77 & 0.145 & 7 & 0.013 & 0.58 & 0.17 & 8 & 0.023 & 1.05 & 0.11 & 7 \\
\hline
\end{tabular}

* Crea $\mathrm{N} .+\mathrm{NH}_{3} \mathrm{~N}=1.85 \mathrm{gm} .=83$ per cent. total $\mathrm{N}$. 
TABLE 3.-Dog 3. Nitrogen Partition BEFORE THYROIDECTOMY

\begin{tabular}{|c|c|c|c|c|c|c|c|c|c|c|c|c|c|c|c|c|c|}
\hline \multirow{2}{*}{ Day } & \multirow{2}{*}{$\begin{array}{l}\text { Wt., } \\
\text { Kg. }\end{array}$} & \multirow{2}{*}{$\begin{array}{l}\text { Glu- } \\
\text { eose, } \\
\text { Fed, } \\
\text { Gm. }\end{array}$} & \multirow{2}{*}{$\begin{array}{c}\text { Vol. } \\
\text { Urine, } \\
\text { C.c. }\end{array}$} & \multirow{2}{*}{$\mid \begin{array}{c}\text { Total } \\
\mathbf{N}, \\
\mathbf{G m} .\end{array}$} & \multirow{2}{*}{$\begin{array}{c}\mathbf{N} \\
\text { per } \\
\mathbf{K g} .\end{array}$} & \multicolumn{2}{|c|}{ Urea $\mathbf{N}$} & \multicolumn{2}{|c|}{$\mathrm{NH}_{\mathbf{N}}$} & \multicolumn{2}{|c|}{ Purin } & \multicolumn{2}{|c|}{$\underset{\mathbf{N}}{\text { Creatin }}$} & \multicolumn{2}{|c|}{ Creatinin } & \multicolumn{2}{|c|}{ Rest } \\
\hline & & & & & & $\overline{\mathrm{Gm}}$. & $\%$ & Gm. & $\%$ & $\mathrm{Gm}$. & $\%$ & Gm. & $\%$ & Gm. & $\%$ & Gm. & $\%$ \\
\hline 1 & 7.5 & $\ldots$ & 325 & 2.17 & 0.289 & 1.71 & 79.0 & 0.096 & 4.45 & 0.011 & 0.507 & 0.069 & 3.25 & 0.036 & 1.66 & 0.248 & 11.4 \\
\hline 2 & 7.4 & $\ldots$ & 305 & 2.13 & 0.288 & 1.73 & 81.1 & 0.101 & 4.76 & 0.012 & 0.563 & 0.069 & 3.24 & 0.085 & 1.64 & 0.183 & \\
\hline 3 & 7.2 & 108 & 265 & 1.82 & 0.253 & 1.19 & 65.2 & 0.092 & 5.12 & 0.011 & 0.604 & 0.071 & 3.90 & 0.087 & 2.08 & 0.419 & 23.0 \\
\hline 4 & 7.2 & 108 & 250 & 1.43 & 0.199 & 0.77 & 53.9 & 0.166 & 11.6 & $0.00 y$ & 0.629 & 0.069 & 4.82 & 0.087 & 2.59 & 0.398 & 27.8 \\
\hline 5 & 7.2 & 108 & 240 & 1.43 & 0.199 & 0.79 & 55.0 & 0.152 & 10.6 & 0.009 & 0.629 & 0.069 & 4.82 & 0.018 & 1.26 & 0.392 & 27. \\
\hline 6 & 7.1 & ... & 400 & 1.62 & 0.228 & 1.21 & 74.8 & 0.138 & 8.49 & 0.004 & 0.247 & 0.068 & 4.20 & 0.015 & 0.93 & 0.173 & 10.7 \\
\hline 7 & 6.9 & $\ldots$ & 250 & 1.63 & 0.236 & 1.21 & 74.4 & 0.100 & 6.16 & 0.008 & 0.491 & 0.069 & 4.23 & 0.023 & 1.41 & 0.220 & 13.5 \\
\hline
\end{tabular}

AFTER THYROIDECTOMY

\begin{tabular}{l|l|l|l|l|l|l|l|l|l|l|l|l|l|l|l|l|l|l|l|l}
\hline 1 & 7.0 & $\ldots$. & 250 & 2.65 & 0.379 & 1.92 & 72.5 & 0.50 & 19.7 & 0.007 & 0.26 & 0.062 & 2.3 & 0.037 & 1.4 & 0.12 & 4.5 \\
2 & 6.9 & $\ldots$ & 290 & 2.72 & 0.395 & 1.99 & 73.1 & 0.46 & 16.9 & 0.007 & 0.24 & 0.055 & 2.8 & 0.043 & 1.6 & 9.16 & 5.9 \\
3 & 6.8 & $\ldots .$. & 320 & 2.94 & 0.433 & 2.13 & 72.5 & 0.60 & 20.5 & 0.007 & 0.24 & 0.056 & 1.9 & 0.048 & 1.6 & 0.10 & 3.4 \\
4 & 6.7 & 100.5 & 235 & 2.73 & 0.408 & & & & & & & & & & & & \\
5 & 6.7 & 100.5 & 225 & 2.07 & 0.369 & & & & & & & & & & & \\
6 & 6.7 & 100.5 & 285 & 1.99 & 0.278 & & & & & & & & & & & \\
7 & 6.55 & $\ldots .$. & 210 & 2.13 & 0.325 & & & & & & & & & & & & \\
8 & 6.55 & $\ldots .$. & 345 & 3.09 & 0.472 & & & & & & & & & & & & & & &
\end{tabular}

TABLE 4.-Dog 4. Nitrogen Partition BEFORE THYROIDECTOMY

\begin{tabular}{|c|c|c|c|c|c|c|c|c|c|c|c|c|c|c|c|c|c|}
\hline \multirow{2}{*}{ Day } & \multirow{2}{*}{$\begin{array}{l}\text { Wt., } \\
\text { Kg. }\end{array}$} & \multirow{2}{*}{$\begin{array}{l}\text { Glu- } \\
\text { cose, } \\
\text { Fed, } \\
\text { Gm. }\end{array}$} & \multirow{2}{*}{$\begin{array}{l}\text { Vol. } \\
\text { Urine, } \\
\text { O.c. }\end{array}$} & \multirow{2}{*}{$\begin{array}{c}\text { Total } \\
\text { N, } \\
\text { Gm. }\end{array}$} & \multirow{2}{*}{$\begin{array}{c}\mathbf{N} \\
\text { per } \\
\text { Kg. }\end{array}$} & \multicolumn{2}{|c|}{ Urea $\mathbf{N}$} & \multicolumn{2}{|c|}{$\underset{\mathbf{N}}{\mathrm{NH}_{3}}$} & \multicolumn{2}{|c|}{ Purin } & \multicolumn{2}{|c|}{$\underset{N}{\text { Creatin }}$} & \multicolumn{2}{|c|}{$\underset{\mathbf{N}}{\text { Creatinin }}$} & \multicolumn{2}{|c|}{$\underset{N}{\text { Rest }}$} \\
\hline & & & & & & Gm. & $\%$ & $\mathrm{Gm}$. & $\%$ & $\mathrm{Gm}$ & $\%$ & $\mathrm{Gm}$. & $\%$ & $\mathrm{Gm}$. & $\%$ & Gm. & $\%$ \\
\hline 1 & 6.3 & $\cdots$ & 235 & 1.95 & 0.309 & 1.62 & 83.0 & 0.079 & 4.07 & 0.008 & 0.41 & 0.060 & 3.0 & 0.026 & 1.3 & 0.157 & 8.0 \\
\hline $2^{*}$ & 6.2 & $\cdots \cdot$ & 275 & 1.88 & 0.303 & & & & & & & & & & & & \\
\hline 3 & 6.0 & $\cdots$ & 235 & 1.60 & 0.267 & 1.32 & 82.5 & 0.053 & 3.28 & 0.006 & 0.37 & 0.060 & 3.7 & 0.026 & 1.6 & 0.135 & 8.4 \\
\hline 4 & 5.9 & . & 230 & 1.65 & 0.280 & 1.38 & 83.8 & 0.051 & 3.06 & 0.007 & 0.42 & 0.060 & 3.6 & 0.030 & 1.8 & 0.121 & 7.4 \\
\hline 5 & 5.8 & 87.0 & 220 & 1.35 & 0.233 & 0.90 & 66.3 & 0.090 & 6.66 & 0.010 & 0.74 & 0.057 & 4.2 & 0.035 & 2.5 & 0.262 & 19.2 \\
\hline 6 & 5.7 & 85.5 & 115 & 1.16 & 0.203 & 0.75 & 64.6 & 0.078 & 6.71 & 0.006 & 0.51 & 0.060 & 5.1 & 0.044 & 3.7 & 0.222 & $\mid 19.1$ \\
\hline 7 & 5.7 & 85.5 & 205 & 1.28 & 0.224 & 0.82 & 64.0 & 0.090 & 7.03 & 0.008 & 0.67 & 0.060 & 4.7 & 0.036 & 2.8 & 0.266 & 20.4 \\
\hline 8 & 5.6 & $\cdots$ & 225 & 1.23 & 0.220 & $t$ & $\ldots$ & $\ldots$ & $\cdots$ & 0.009 & 0.73 & 0.056 & 4.5 & 0.029 & 2.3 & 0.156 & 12.7 \\
\hline
\end{tabular}

AFTER THYROIDECTOMY

\begin{tabular}{l|r|l|l|l|l|l|l|l|l|l|l|l|l|l|l|l|r|r}
\hline 1 & 5.30 & $\ldots$ & 105 & 1.85 & 0.349 & 1.52 & 82.1 & 0.089 & 4.8 & 0.005 & 0.28 & 0.061 & 3.08 & 0.038 & 1.9 & 0.14 & 7.6 \\
2 & 5.25 & $\ldots$ & 210 & 1.71 & 0.326 & 1.33 & 77.8 & 0.087 & 5.0 & 0.005 & 0.30 & 0.058 & 3.10 & 0.036 & 2.0 & 0.20 & 11.7 \\
3 & 5.10 & $\ldots$. & 185 & 1.51 & 0.300 & 1.25 & 82.7 & 0.080 & 5.3 & 0.005 & 0.33 & 0.056 & 3.71 & 0.020 & 1.3 & 0.10 & 6.6 \\
4 & 5.00 & $\ldots$. & 155 & 1.60 & 0.320 & 1.33 & 83.1 & 0.086 & 5.3 & 0.005 & 0.31 & 0.057 & 3.56 & 0.019 & 1.2 & 0.10 & 6.2 \\
$5^{*}$ & 4.95 & 73.0 & 155 & & & & & & & & & & & & & \\
6 & 5.00 & 73.0 & 105 & 0.98 & 0.196 & & & & & & & & & & & \\
7 & 5.00 & 73.0 & 170 & 0.93 & 0.186 & & & & & & & & & & & \\
8 & 5.00 & $\ldots$. & 200 & 0.98 & 0.196 & & & & & & & & & & & \\
9 & 4.95 & $\ldots$ & 255 & 1.43 & 0.287 & & & & & & & & & & & \\
\hline
\end{tabular}

* Specimen contaminated with feces.

+ Urea $\mathrm{N}+\mathrm{NH}_{3} \mathrm{~N}=0.98 \mathrm{gm} . \stackrel{=}{=} 80$ per cent. total $\mathrm{N}$.

Downloaded From: http://archinte.jamanetwork.com/ by a UQ Library User on 06/16/2015 
This must be borne in mind in interpreting the results. It is also to be remembered that it requires a certain length of time for the myxedematous condition to develop after thyroidectomy. The metabolic disturbances reported by us, observed as they were at most a few weeks after the operation, are probably to be regarded as incipient.

Weight: Three of the four dogs had lost weight at the time of the examination and one had gained. The primary loss of weight may be caused by defective tissue nutrition due to the failure of thyroid function. Later, obesity tends to develop.

Nitrogen: The nitrogen excretion showed an inconstant variation. In two dogs it was diminished, in Dog 3 distinctly increased, while in Dog 4 no definite change took place. A decrease in the nitrogen elimination after thyroidectomy has been recorded by others. ${ }^{7}$ Underhil! and Hildilch ${ }^{8}$ observed no very definite change.

Urea and Ammonia Excretion: The urea and ammonia varied in general with the total nitrogen excretion. In estimating changes in the metabolism, the experimental days on which glucose was fed are omitted from this discussion, as sugar disturbs the equilibrium of the nitrogen metabolites in the urine. The ammonia-nitrogen curve parallel's, as usual, the total nitrogen, except in the case of Dog 3, in which animal it was unusually increased after thyroidectomy.

Purins: Here the most striking changes were observed. In every instance the thyroidectomy was followed by a distinct diminution in the purins, as the average values in the accompanying tables demonstrate. These results appear to be the only ones recorded definitely indicating that the normal level of endogenous purin metabolism is maintained by the thyroid. The significance of this finding will be discussed later.

Creatinin: This remained practically uninfluenced by thyroidectomy except in Dog 1, in which it was somewhat increased. None of our work shows any definite influence of the thyroid on creatinin metabolism. The creatinin excretion showed its usual tendency to remain almost constant from day to day.

Creatin: This substance is usually present in dog urine, though abnormal in the urine of man. It showed fluctuations from zero in Dog. 2 after the operation to an increase after thyroidectomy in Dog 4. Creatin excretion is subject to wide variations, due to different causes, which have been discussed previously by Shaffer. ${ }^{9}$ Such causes

7. Hunter, A.: Quart. Jour. Exper. Physiol., 1914, 8, 21. Greenwald, I.: Biochem. Ztschr., 1913, 14, 363. 25, 66

8. Underhill, F. P., and Hildilch, W. W.: Am. Jour. Physiol., 1909-1910,

9. Shaffer, P. A.: Am. Jour. Physiol., 1908, 23, 1. 
were evidently exerting their influence here. We were unable to detect any changes in the creatin metabolism definitely referable to thyroidectomy.

III. METABOLISM IN EXPERIMENTAL HYPERTHYROIDISM

1. Experimental Plan.-The effect of administering large amounts of thyroid substance on the urinary end-products of protein metabolism has been obscured in previous experiments through the introduction and consequent effect on the results of the protein, purin, etc., in the thyroid material ingested. To avoid this source of uncertainty we made use of a concentrated solution of the thyroid hormone isolated and kindly donated by Dr. E. C. Kendall of the Mayo Clinic. This was

TABLE 5.-Hormone EXPERIMENT

\begin{tabular}{|c|c|c|c|c|c|c|c|c|c|c|c|c|c|c|c|c|c|c|c|}
\hline \multirow{3}{*}{ Day } & \multirow{3}{*}{$\begin{array}{l}\text { Wt., } \\
\text { Kg. }\end{array}$} & \multirow{3}{*}{$\begin{array}{l}\text { Glu- } \\
\text { cose } \\
\text { Fed, } \\
\text { Gm. }\end{array}$} & \multirow{3}{*}{$\begin{array}{c}\text { Vol. } \\
\text { Urine, } \\
\text { C.e. }\end{array}$} & \multirow{3}{*}{$\begin{array}{c}\text { Total } \\
\text { N, } \\
\text { Gm. }\end{array}$} & \multirow{3}{*}{$\begin{array}{c}\mathbf{N} \\
\text { per } \\
\text { Kg. }\end{array}$} & \multirow{2}{*}{\multicolumn{2}{|c|}{$\underset{\mathrm{N}}{\text { Urea }}$}} & \multirow{2}{*}{\multicolumn{2}{|c|}{$\underset{\mathrm{N}}{\mathrm{NH}}$}} & \multirow{2}{*}{\multicolumn{2}{|c|}{$\underset{\mathbf{N}}{\text { Purin }}$}} & \multirow{2}{*}{\multicolumn{2}{|c|}{$\underset{N}{\text { Creatinin }}$}} & \multirow{2}{*}{\multicolumn{2}{|c|}{$\underset{N}{\text { Creatin }}$}} & \multirow{2}{*}{\multicolumn{2}{|c|}{$\underset{N}{\text { Rest }}$}} & \multicolumn{2}{|c|}{ Special } \\
\hline & & & & & & & & & & & & & & & & & & \multirow{2}{*}{$\begin{array}{l}\text { Hor- } \\
\text { mone } \\
\text { In- } \\
\text { jected, } \\
\text { C.c. }\end{array}$} & \multirow{2}{*}{$\begin{array}{l}\text { Uri- } \\
\text { nary } \\
\text { Glu- } \\
\text { cose, } \\
\text { Gm. }\end{array}$} \\
\hline & & & & & & Gm. & $\%$ & Gin. & $\%$ & Gm. & $\%$ & Gm. & $\%$ & Gm. & $\%$ & Gm. & $\%$ & & \\
\hline 1 & 14.5 & $\ldots$ & 550 & 3.39 & 0.234 & 2.61 & 77 & 0.33 & 10 & 0.0056 & 0.16 & 0.19 & 5.6 & 0.0 & 0.0 & 0.25 & 7.5 & & \\
\hline 2 & 14.8 & $\ldots$ & 720 & 3.28 & 0.222 & 2.57 & 78 & 0.26 & 8 & 0.0112 & 0.34 & 0.19 & 5.6 & 0.0 & 0.0 & 0.25 & 7.6 & & \\
\hline 3 & 14.4 & $\ldots$ & 610 & 3.36 & 0.233 & 2.79 & 83 & 0.20 & 6 & 0.0098 & 0.26 & 0.18 & 5.4 & 0.0 & 0.0 & 0.18 & 5.3 & & \\
\hline 4 & 14.1 & $\cdots$ & 820 & 4.75 & 0.337 & 4.18 & 88 & 0.25 & 6 & 0.0147 & 0.30 & 0.19 & 4.0 & 0.038 & 0.8 & 0.08 & 1.7 & 35 & \\
\hline 5 & 13.5 & $\ldots$ & 510 & 5.52 & 0.409 & 4.54 & 82 & 0.30 & 5 & 0.02224 & 0.40 & 0.19 & $3 . \overline{0}$ & 0.125 & 2.2 & 0.34 & 6.1 & 15 & \\
\hline 6 & 13.2 & 198 & 330 & 4.82 & 0.365 & 4.04 & 83 & 0.29 & 6 & 0.0217 & 0.45 & 0.19 & 3.8 & 0.070 & 1.4 & 0.21 & 4.3 & 15 & 2.2 \\
\hline 7 & 13.4 & 201 & 680 & 5.07 & 0.378 & 4.06 & 80 & 0.37 & 7 & 0.0310 & 0.61 & 0.19 & 3.8 & 0.166 & 3.2 & 0.25 & 4.9 & 15 & Trace \\
\hline 8 & 13.0 & $\ldots$ & 850 & 7.26 & 0.558 & 5.70 & 78 & 0.71 & 10 & 0.0430 & 0.59 & 0.19 & 2.5 & 0.085 & 1.1 & 0.54 & 7.4 & & \\
\hline 9 & 12.6 & $\cdots$ & 520 & 6.28 & 0.498 & 4.63 & 73 & 0.85 & 13 & 00220 & 0.35 & 0.15 & 2.3 & 0.066 & 1.0 & 0.56 & 8.8 & & \\
\hline 10 & 12.3 & $\ldots$ & 440 & 6.31 & 0.513 & $\ldots$ & . & $\ldots$ & $\ldots$ & & & & & & & & & & \\
\hline
\end{tabular}

analyzed by us. The doses administered contained so little nitrogen that the results cannot be influenced as mentioned. That this hormone preparation was active is not to be doubted, for it exerted a therapeutic effect on a cretin, as will be reported later in an experimental study of thyroid therapy.

The scheme adopted was to determine the normal fasting metabolism of nitrogen, urea, ammonia, etc., of a dog, after which large doses of the sterile hormone were injected subcutaneously. The methods employed have been alluded to in Section 2. The first hormone injection consisted of 35 c.c., which amount was reduced thereafter, 15 c.c. of the hormone being given daily. One c.c. of this liquid contained $0.96 \mathrm{mg}$. iodin, equivalent to about $3 \mathrm{mg}$. hormone. No local necrosis or infection followed the hormone injections. The 
metabolic procedure was otherwise exactly that employed in the thyroidectomy experiments, fasting being maintained throughout.

2. Results.-This experiment afforded highly instructive results. $\Lambda$ relatively enormous amount of the thyroid hormone was suddenly thrown into the organism. There ensued a latent period lasting until the following day. This phenomenon has been observed by Kendall. Then the temperature rose. The dog's skin became reddened. Hyperexcitability to touch developed, muscle twitchings following the slightest stimulus, increased reflexes and a distinct fine tremor of the paws were present. No exophthalmos was observed. It may be remarked that exophthalmos is very rarely seen in such experiments. Thus, Lampe, Liesegang and Klose ${ }^{10}$ in their exhaustive monograph on exophthalmic goiter and experimental hyperthyroidism, report that they were able experimentally to produce protruding eyeballs only in certain degenerative strains of fox terriers. The clinical appearance of our animal was, with the exception noted, that of typical hyperthyroidism. After the hormone injections were discontinued, the symptoms gradually subsided.

Metabolism: Before the injections were given the excretion of the urinary nitrogenous substances was quite normal and regular, but thereafter a veritable metabolic storm broke loose. The total nitrogen practically doubled in amount during the next few days and remained high even after the hormone administration had ceased. The amounts of urea, ammonia and purins became correspondingly elevated. It is a remarkable fact that the creatinin remained absolutely unresponsive to this tremendous stimulus, and maintained its unchanged level throughout the experiment. Creatin, although absent previous to the injection, appeared in the urine in considerable amounts. The significance of this phenomenon is probably as follows: the hormone evidently caused a large increase of tissue and muscular breakdown of which creatin excretion is an evidence, providing, as in this case, it has been previously absent from the urine. The purin excretion of hyperthyroidism is especially interesting in view of the fact that the thyroidectomy experiments demonstrated that the purin metabolism is at least partly controlled by the thyroid. The purin elimination enormously increased during the period of hyperthyroidism; indeed, to the extent of 300 per cent.

Previous observations on the effect on the urinary nitrogen metabolites following the administration of thyroid material are but fragmentary. Cramer and Krause ${ }^{11}$ observed what must of course take

10. Lampe, E., Liesegang, R. E., and Klose, H.: Beitr. z. klin. Chir., 1912, 77, 757.

11. Cramer, W., and Krause, R. A.: Physiol. Soc. Proc., 1912, 23, Jour. Physiol., 1912, 44, 2. 
place, that when the total nitrogen is increased by feeding thyroid material, a corresponding rise in the urea elimination ensues. Creatin appeared in the urine of their patient.

The Protein Sparing Action of Carbohydrates in Athyroidism and Hyperthyroidism. - In the foregoing experiments opportunity was afforded for testing an interesting hypothesis of special scientific interest. A recent research by $u^{2}$ has emphasized the important influence exerted by the thyroid gland on carbohydrate metabolism. Carbohydrates when taken into the body are known to limit protein breakdown. This process is most plausibly explained by the hypothesis that they thus "spare" protein by affording materials which are built up into protein, perhaps thus limiting tissue loss. The thyroid is now recognized as having a decided influence on the growth and nutrition of the tissues. If we then estimate the degree of protein-sparing by carbohydrate before and after thyroidectomy, we can determine whether this process is a function of the thyroid, consequently whether the thyroid possibly builds up the tissues by means of metabolic products of carbohydrates. The results of these experiments are quite negative. Glucose, as the protocols clearly show, spared usually as much protein before as after thyroidectomy. This action is therefore not controlled by the thyroid gland so far as is indicated by these experiments. This result has no special clinical significance. It only shows that in cretinism and myxedema the normal relationship of carbohydrate to protein metabolism is maintained.

Carbohydrate was also administered in the hyperthyroidism experiment. This was done in order to determine the effect of carbohydrate on the abnormally increased nitrogen metabolism observed in this condition. The protocol of this experiment shows no definite decrease in the total nitrogen and urea, and a decided increase in the purin excretion on the sugar days. During the following days all these substances were markedly increased. In interpreting these results one must bear in mind that during the injection days there was a tendency for a greater excretion of all the urinary substances examined, a result of the increasing toxic effect of the hormone. That this is true is demonstrated by a study of the purin elimination, which was largely increased even on the sugar days. Former investigation has shown that the effect of sugar on the protein metabolism is limited to urea and ammonia. The purins remained unaffected by the ingested glucose and were consequently relatively augmented in percentage. The ammonia in our case was not depressed by the sugar ingested. In view of this evidence of increasing tissue breakdown, the failure of the total nitrogen and urea to be decreased by the sugar administration, is not surprising, for without it the nitrogen and urea would likely have been excreted in increased amounts. The experiment is then 
rather to be accepted as indicating that glucose exerts its sparing effect on protein metabolism also in hyperthyroidism. This experiment would thus offer an explanation for the results obtained by us in other experiments, to be reported later, showing that exophthalmic goiter patients do best on a mixed diet containing large amounts of nomnitrogenous foods, as the toxic loss of protein is partially combated in this way. The question of diet in thyroid diseases will be discussed in detail in a later communication.

\section{CLINICAL METABOLISM EXPERIMENTS}

1. Clinical Material.-The cases included in the present study will be reported in detail in the third of this series of articles and are therefore but briefly extracted here.

CAsE 1.-Typical Cretin, Y. K., woman, aged 23; possessed the usual characteristics: short stature, pendulous abdomen, coarse skin, thickened nose and lips, defective teeth and nails; mental development, that of a child of 6 years. The patient, who remained in the metabolic ward for nearly a year, improved somewhat on thyroid treatment.

CASE 2.-Exophthalmic goiter; A. H., man, aged 30; history of great loss of weight, increasing weakness and nervousness. The patient showed emaciation, constant fine tremor of hands, muscle twitchings, moist skin, large struma, with loud systolic bruit, marked exophthalmos; Stelwagen's and von Graefe's sign present. Prolonged metabolic studies demonstrated that his general metabolism was markedly increased, for it was necessary for him to consume 60 calories per kilogram to maintain weight equilibrium.

2. Experimental Plan.-Use was made of the advantages offered by a metabolism ward, special diet kitchen and nurses trained in metabolism work. The technic employed by us in metabolic examinations of patients has been previously described in various publications, and therefore scarcely requires a detailed presentation. The usual care was given to the weighing of the food and collection of the excreta. The patients had already undergone a careful training in the ward, where they had been for several months for other experimental purposes. The results may be therefore regarded as reliable. The diet was purin-free for one week prior to and during the examination, was weighed and consisted of the following articles: oatmeal, farina, rice, egg, corn, tomato, onions, bread, butter, crackers, milk, orange, prunes, pears.

Under these conditions nitrogen partitions as before were carried out on these patients with an idea of determining the influence of thyroid disease on the urinary nitrogen metabolites.

3. Nitrogen Partition in Cretinism.-The total nitrogen of the diet, as the protocols show, about equals the output, so that little nitrogen was lost or retained. The nitrogen elimination was low, but this seems due rather to the low protein, high carbohydrate and fat diet which necessarily constitutes a purin-free régime, than to any inherent ten- 
dency of the cretin to a low nitrogen excretion. The urea, ammonia and creatinin showed normal variations. Creatin was present, which is abnormal. The purin nitrogen and phosphates ranged in the lower level of the normal excretion of these substances. The purins averaged $0.119 \mathrm{gm}$. daily. Normal variations are 0.08 to $0.25 \mathrm{gm}$. daily.

Scholz ${ }^{12}$ has previously studied the urine of cretins in an extensive research published in 1905 when, unfortunately, few of the analytic methods were very reliable. This fact, together with the uncertain

TABLE 6.-Y. K.; Cretin. Urinary Nitrogen Partition

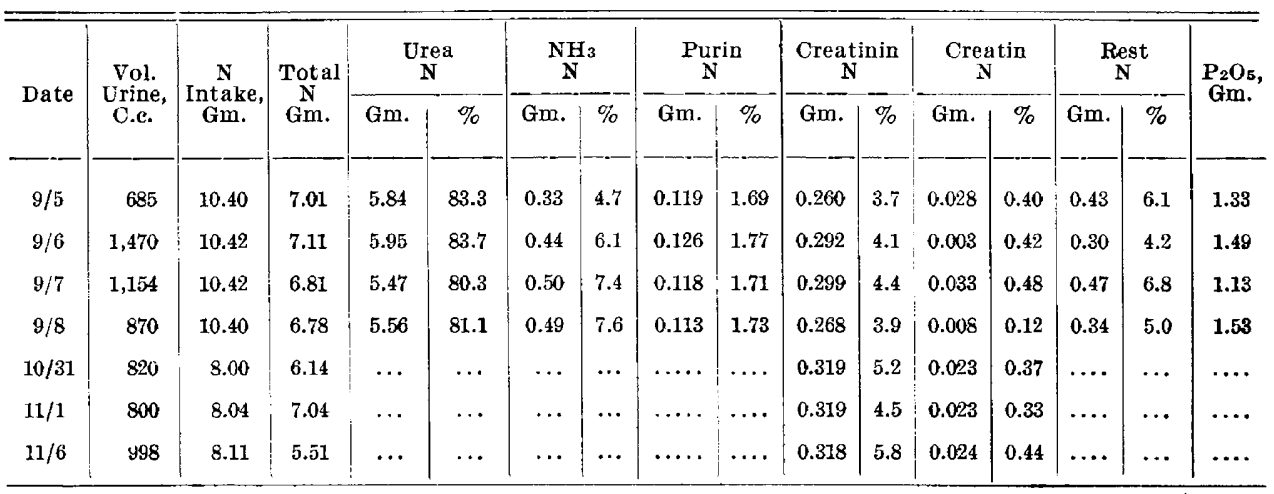

TABle 7.-J. H. Exophthalmic Gorter. Urinary Nitrogen Partition

\begin{tabular}{|c|c|c|c|c|c|c|c|c|c|c|c|c|c|c|c|c|}
\hline \multirow{2}{*}{ Date } & \multirow{2}{*}{$\begin{array}{c}\text { Vol. } \\
\text { Urine, } \\
\text { C.c. }\end{array}$} & \multirow{2}{*}{$\underset{\substack{\mathbf{N} \\
\text { Gm. } \\
\text { Gme, }}}{ }$} & \multirow{2}{*}{$\underset{\text { Gotal }}{\mathbf{N}}$} & \multicolumn{2}{|c|}{$\underset{\mathbf{N}}{\text { Urea }}$} & \multicolumn{2}{|c|}{$\underset{\mathrm{N}}{\mathrm{NH}}$} & \multicolumn{2}{|c|}{$\underset{\mathrm{N}}{\text { Purin }}$} & \multicolumn{2}{|c|}{$\underset{\mathbf{N}}{\text { Creatinin }}$} & \multicolumn{2}{|c|}{$\underset{N}{\text { Creatin }}$} & \multicolumn{2}{|c|}{$\underset{\mathbf{N}}{\text { Rest }}$} & \multirow{2}{*}{$\begin{array}{l}\mathrm{P}_{2} \mathrm{Os}_{\text {s, }} \\
\mathrm{Gm} .\end{array}$} \\
\hline & & & & Gm. & $\%$ & Gm. & $\%$ & Gm. & $\%$ & Gm. & $\%$ & $\mathrm{Gm}$. & $\%$ & Gm. & $\%$ & \\
\hline $9 / 5$ & 1,320 & 14.94 & 9.84 & 7.40 & 75.0 & 0.85 & 8.6 & 0.191 & 1.9 & 0.354 & 3.6 & 0.041 & 0.41 & 1.01 & 10.0 & 2.25 \\
\hline $9 / 7$ & 1,245 & 14.94 & 9.80 & 7.35 & 74.1 & 0.90 & 8.3 & 0.162 & 1.6 & 0.352 & 3.6 & 0.0 & 0.0 & 1.04 & 10.6 & 2.35 \\
\hline $10 / 31$ & 1,300 & 11.68 & 7.96 & $\ldots$ & $\ldots$ & $\ldots$ & $\ldots$ & 0.123 & 1.5 & 0.362 & 4.5 & 0.023 & 0.30 & $\ldots$ & . & $\ldots$ \\
\hline $11 / 1$ & 1,500 & 11.50 & 7.99 & ... & $\ldots$ & $\ldots$ & $\ldots$ & 0.086 & 1.1 & 0.323 & 4.0 & 0.023 & 0.29 & .... & . & $\ldots$ \\
\hline $11 / 6$ & 1,410 & 11.85 & 9.76 & $\ldots$ & $\ldots$ & $\ldots$ & ... & 0.040 & 0.5 & 0.328 & 3.4 & 0.047 & 0.48 & $\ldots$ & $\ldots$ & $\cdots$ \\
\hline
\end{tabular}

activity of the thyroid preparations used at the time, would adequately account for the considerable variations shown by his results. His work, however, indicated that in the cretin, uric acid and phosphates and creatinin, the last in variance with our results, were eliminated in decreased amounts. McCrudden ${ }^{13}$ found creatin present in the urine of a cretin, also in cases of infantilism and achondroplasia. Greenwald ${ }^{14}$ confirmed certain of these results.

12. Scholz, W.: Ztschr. f. exper. Path. u. Therap., 1905-1906, 2, 271.

13. McCrudden, F. H.: Jour. Exper. Med., 1912, 15, 467.

14. Greenwald, I.: The Archives Int. Med., 1914, 14, 374. 
4. Nitrogen Partition in Exophthalmic Goiter.-In these experiments the total nitrogen in the urine was found to about equal the intake. Protein metabolism in this case was undoubtedly increased, as a long series of later observations not appearing in this article, amply demonstrated. The urea nitrogen was normal in percentile relation to the total nitrogen. The ammonia tended to be high. In three of the four partition days, creatin was present in the urine. That creatin was consistently excreted in this case is shown by subsequent examinations as follows: Oct. 31, 1916, creatin $0.023 \mathrm{gm}$; Nov. 1, 1916, creatin 0.023 gm.; Nov. 6, 1916, creatin $0.047 \mathrm{gm}$. The purin nitrogen and phosphate excretion were at the upper level of normal. In view of the striking increase of purin metabolism found by us in experimental hyperthyroidism, it is more likely that the purins will, on examination of a series of cases of uncomplicated hyperthyroidism, be likewise found increased rather than decreased, as reported by Falta and Zehner. ${ }^{15}$ The creatinin in our case was a little low. Forschbach ${ }^{16}$ has reported the same observation. As creatinin remains unaffected in experimental hyperthyroidism (see the foregoing), it is probable that its increase here is to be explained by the fact that sometimes the appearance of creatin is accompanied by a diminution of the amount of creatinin eliminated, the creatin being apparently formed at the expense of the creatinin. Excretion of creatin in exophthalmic goiter has been studied by Shaffer ${ }^{9}$ and has been observed by others.

\section{v. DISCUSSION AND CONCLUSIONS}

We may now endeavor to piece together the results of the nitrogen fartitions in the various experiments described, and draw from them what general conclusions are justified with regard to the urinary nitrogenous substances in our studies. No selective action of the thyroid was observed on urea and ammonia. The percentages of these substances remained within normal limits. The amounts present varied with the total nitrogen, in the usual manner. Our experimental studies definitely demonstrate that the thyroid exerts an influence on purin metabolism, as we observed both a decrease in the urinary purins after thyroidectomy and a marked increase in experimental hyperthyroidism; also a tendency to a low purin excretion in the cretin and a high excretion in a case of exophthalmic goiter. The clinical observations thus tend to confirm the experimental findings but should be extended before conclusions are justified.

The behavior of the purin metabolism in hypophysial disease seems to be analogous to that in thyroid disease. In the few cases investi-

15. Falta, W.: Die Erkrankungen der Blutdrusen, Berlin, 1913, p. 66.

16. Forschbach: Arch. f. exper. Path. u. Pharmakol., 1907, 63, 113. 
gated, the endogenous purin excretion is reported high in acromegaly by Falta and Nowaczynski. ${ }^{17}$ The same investigators found a decreased uric acid elimination in hypopituitarism (Fröhlich's syndrome). The observation that the thyroid exerts an influence over purin metabolism analogous to the effect of the hypophysis is important, and a further illustration of the fact which is becoming more and more apparent, namely, that several of the endocrine organs may exert very similar influences on the metabolic processes.

With regard to clinical applications, it might seem, in view of these results, justifiable to seek the cause of gout in an endocrine disturbance. So far, however, as the thyroid and hypophysis are concerned, clinical observations do not support a relation of diseases of these organs to gout. One might likewise feel inclined to administer thyroid or pituitary tablets to gouty patients in the hope of stimulating the excretion of the purins. According to our views, however, this would scarcely be advisable, at least in the case of thyroid, for it is probable that the excretion of purins is increased only as the result of a toxic effect of large doses of thyroid on the protein of the tissues (compare hormone experiment).

Our studies emphasize the independence of the creatinin metabolism from thyroid influence. Creatinin was not increased in the urine even when large amounts of body tissue were being broken down in experimental hyperthyroidism. This would seem to indicate that creatinin is not a direct product of protein catabolism. With regard to creatin, it is indeed strange that a product which is chemically merely hydrated creatinin should appear in the urine while the creatinin undergoes but little change. This apparent independence of creatin from creatinin metabolism is striking. A number of previous observations have, however, shown this to occur under other circumstances.

In the thyroidectomy experiments the creatin determinations are not very valuable, as this substance is usually present in normal dog urine. However, the fact that it is found in cretinism and exophthalmic goiter deserves consideration. Creatin is usually excreted when masses of body tissue are being broken down, such as takes place in severe febrile conditions. Such is, however, not the case in cretinism. Its appearance in this condition is probably due to a disturbance in the normal synthetic metabolic processes which take place by means of intermediary chemical reactions which are as yet little understood, but may be disturbances in the metabolism of carbohydrates. The creatinuria of exophthalmic goiter seems more easy of comprehension than that of cretinism, for in exophthalmic goiter there is frequently a toxic breakdown of body tissue which may be held to account for the appearance of creatin.

17. Falta, W.: Ductless Glandular Diseases, Philadelphia, 1916, p. 263. 
The present experiments do not support the view that any marked diminution of nitrogen excretion follows thyroidectomy in animals (see the foregoing). Nor was the nitrogen output particularly low in the cretin. There are, moreover, reasons to believe that the decrease in the protein breakdown, observed by others in the cretin metabolism, is due rather to an inability for growth and repair of tissue to take place. These views will be more fully developed in the next article of this series.

We wish to acknowledge the excellent assistance rendered by Miss Maude Hays in the dietetic and analytic work of this research. 